Artículo recibido el 04 de junio de 2020. Aceptado para publicación el 31 de agosto de 2020

\title{
Beyond songs and dances: Ethnomathematics and the challenge of culture
}

\section{Más que canciones y danzas: Etnomatemáticas y el reto de la cultura}

\begin{abstract}
Wilfredo Vidal Alangui ${ }^{1}$
Abstract

In this paper, I discuss the pitfalls of the anthropological notion of culture when used in the field of ethnomathematics, and use Dowling's myth of reference and myth of emancipation to show how these are linked to what I refer to as the dual dangers - the dangers of decontextualization and knowledge colonization in the field of ethnomathematics. I argue that these two dangers arise from a naïve approach to ethnomathematics research that is informed by the anthropological notion of culture. The paper provides some examples from the Philippines and one from New Zealand on how these dual dangers may manifest while pursuing studies in ethnomathematics and programs for culturally relevant mathematics education.
\end{abstract}

Keywords: Ethnomathematics; Culture; Dual dangers; Mutual interrogation.

\section{Resumen}

En este artículo, analizo las trampas de la noción antropológica de cultura, cuando se usa en el campo de la etnomatemática, y utilizo los mitos de referencia y de la emancipación planteados por Dowling para mostrar cómo están vinculados a lo que denomino como los peligros duales: los peligros de la descontextualización y colonización del conocimiento en el campo de la etnomatemática. Sostengo que estos dos peligros surgen de un acercamiento ingenuo a la investigación Etnomatemática que se basa en la noción antropológica de cultura. El artículo trae algunos ejemplos de Filipinas y uno de Nueva Zelanda, sobre cómo estos peligros duales pueden manifestarse cuando se realizan estudios en etnomatemáticas y programas de educación matemática culturalmente relevante.

Palabras claves: Etnomatemáticas; Cultura; Peligros duales; Interrogación mutua.

\section{INTRODUCTION}

As a program of study looking at the interplay of mathematic and culture, ethnomathematics argues that culture impinges on all aspects of knowledge, including mathematics. Embarking on ethnomathematical research, therefore, entails clarifying the concept of culture, because it means different things to different people. There is thus a continuing imperative for

\footnotetext{
${ }^{1}$ Department of Mathematics and Computer Science, College of Science, University of the Philippines Baguio. wvalangui@up.edu.ph
} 
Alangui, W. V. (2019). Beyond songs and dances: Ethnomathematics and the challenge of culture. Revista Latinoamericana de Etnomatemática, 13(3), 88-107. DOI: 10.22267/relatem.20133.63

ethnomathematics scholars to re-view the use of culture as a critical construct in the field. This chapter expounds on a paper presented at the $6^{\text {th }}$ International Congress on Ethnomathematics held at the University of Antioquia, in Medellin, Colombia on 8-13 July 2018 and builds on an earlier work (Alangui, 2010).

As 'culture' continues to be a contested concept and "resists reduction to any single meaning" (Ray, 2001, p. 3), any research in the area of culture must elucidate its own definition of the concept. This is true for ethnomathematics.

The use of culture in the ethnomathematics program has been the subject of critical reflection. Hottinger (2016, p. 129) argues that the field faces "difficult critiques" generally falling into two categories. The first category covers critiques of the field's understanding of mathematics and the second involves critiques on the field's understanding of culture.

Confronting the question of culture does not imply having to agree on one definition. Alangui \& Barton (2002) propose that anyone working in the field of ethnomathematics must be explicit about what they are meaning, arguing that it would better serve ethnomathematicians to have more awareness on the debates within anthropology around the concept of culture. Hence what is needed is for the field of ethnomathematics to examine its assumptions in view of the contested notion of culture, as well as be able to respond to the challenges and difficulties that come with such a conception.

One of the criticisms of Hottinger (2016, p. 141) has to do with the anthropological notion of culture. She claims that ethnomathematics scholars

desire to distance themselves from what many consider to be the neocolonialist, racist project of traditional cultural anthropology. Yet they do this without actually engaging with the scathing critiques of anthropology... And ethnomathematic scholars rarely turn that critical, self-reflexive mirror onto their own field of study.

At the $6^{\text {th }}$ ICEm, I pointed out that this criticism is not entirely accurate, as a growing number of ethnomathematics scholars have recognized and engaged the problematic use of the anthropological notion of culture, and have thus attempted to use a more critical conception of culture in their work. Many have also acknowledged the interplay of power and culture in the areas where they do their ethnomathematics research. For example, the works of Gelsa 
Knijnik (2002), Maria Cecilia Fantinato and Sousa (2016), Charoula Stathopoulou (2016) and Aldo Parra (2017), to name but a few, are informed by the need to acknowledge the dynamics of power and culture, and thus the necessity to use a critical concept of culture away from the anthropological one.

My work (Alangui, 2010) has attempted to respond to the challenges we face in the field with the use of the anthropological notion of culture. This paper is partly my response to Hottinger, and I reiterate a concept of culture that has been informed by, and evolved out of the challenges posed by an uncritical use of the concept. At the same time, I have sounded (Alangui, 2010) the dangers attendant to the use of the anthropological notion of culture, and which continue to beset the field of ethnomathematics based mainly on the experiences in the Philippines. I thus see Hottinger's recent critique as an opportunity for continuing dialogue and debate about how the use of the concept of culture is evolving within the field.

\section{THE NOTION OF A DISCRETE CULTURE}

Many anthropologists have expressed concern on the idea of a single/discrete culture (Strauss, 2000; Peters, 2001), or what is referred to as "the anthropological notion of culture" (McConaghy, 2000, p.xi). Some of these concerns along with the names of the anthropologists who have expressed them are listed below (Strauss, 2000, p. 88):

It implies stasis (Clifford, 1988; Wolf, 1982);

It implies homogeneity within the group whose culture is described (Roberts, 1961; Wallace, 1970);

It implies definite boundaries between entities (the culture of the $\mathrm{x}$, the culture of the $y$ ), overlooking exchanges of ideas, objects, and practices (Appadurai, 1990; Wolf, 1982);

It elides the way representations are disseminated by dominant groups and resisted by nondominant groups (Foucault, 1972; Gramsci, 1971);

It misses the way cultural descriptions sometimes reflect the anxieties of analysts about their own societies more than behaviors in the society being described (Said, 1978), or captures only the official rules proffered by informants, ignoring actual practice (Boas, 1911/1938; Bourdieu, 1972/1977; Malinowski, 1922/1961); and

It creates a fictional single entity out of a diverse set of objects, practices, and mental representations (D'Andrade, 1995).

Furthermore, Peters (2001) argues that the use of the anthropological or discreet notion of culture underestimates the power of subcultures and social movements to redefine cultures. 


\section{LIMITATIONS OF THE ANTHROPOLOGICAL NOTION OF CULTURE}

In Alangui (2010; forthcoming), I summarise the three major limitations in the use of the anthropolocial notion of culture that are related to my work. I argue that this notion of culture has implications in the constructs of change and agency, othering, and the possibilities of interrogation.

\subsection{The Accident of Change and Absence of Agency}

One of the problems with the anthropological notion of culture is that it conjures an image of a homogenous group of people leading an unadulterated life and immune from outside influences. This notion de-emphasises conscious change as well as the role of human agency in culture change. Carrithers (1992, p.8) explains that in this notion of culture, "whatever events and changes that have occurred in a traditional society are merely accidental, epiphenomenal, mere ruffles on the great sea of tradition, stability, and cultural conservatism." At the same time, cultural subjects/human agents are, to borrow McConaghy's words, "either absent or visible only in re-action" (McConaghy, 2000, p. 18).

Viewing cultures as having defined boundaries also glosses over the fact that cultures (and societies) have historically been undergoing processes of interactions, although in varying degrees and in different forms. Wolf (1982) argues that when anthropologists arrived after what is known as the great voyages of discovery (Fritze, 2002), "apparently local and unaffected, groups of people were in fact already deeply entwined in a growing world system of commerce, colonization, and the exercise of imperial power" (Carrithers, 1992, p. 25). Today's world is increasingly internationalised/globalised world. Overlaps, interactions and hybridisations of cultures are happening at an even faster rate, in various expressions and with different outcomes. To not acknowledge these interactions between and among groups of peoples is to ignore the fact that cultures are continually sharing and exchanging ideas, objects and practices (Appadurai, 1990; Wolf, 1982) - the very processes that give impetus to transformation and growth. 


\subsection{Defining the 'Other' and Epistemic Violence}

The idea that cultures are discrete entities has resulted in the construction of the category of the 'other.' Difference is explained through the mutual exclusivity of cultures, making them "ahistorical, observable, and able to be compared" (Vincent, 1991, p. 46). McConaghy (2000) writes of scientific culturalism as one mechanism developed around the anthropological notion of culture to explain "the proliferation of variations in human ways of life" (McConaghy, 2000, p. 96).

This comparison provided the epistemological basis for judging European culture and ways of thinking as superior to non-European ones. For indigenous peoples, scientific culturalism has become one effective mechanism in their 'othering' as well as in the denigration of their forms of knowledge. Because of this, culture becomes one of the principal technologies in the twentieth century by which indigenous peoples "are objectified, dehumanized and designated as alterior" (McConaghy, 2000, p. 97).

The irony is that whilst the notion of 'discrete and bounded cultures' ignores, or downplays historical interaction and negotiation of cultures, certain forms of these processes facilitated the subjugation of one culture by another. As an uneven interaction characterised by violence and domination, colonialism is one such process.

The experience of indigenous peoples under colonialism explains how certain types of knowledge have come to be dominant over others. For Smith (1999, p. 64), colonialism:

... not only meant the imposition of Western authority over all aspects of indigenous lands, indigenous modes of production and indigenous law and government, but the imposition of Western authority over all aspects of indigenous knowledges, languages and cultures.

With culture being at the heart of the anthropological endeavour, McConaghy (2000) makes a case about the complicity of anthropology and colonialism in the propagation and imposition of Western forms of knowledge through what Gayatri Chakravorti Spivak calls epistemic violence against other forms of knowledge. She argues that (McConaghy, 2000, p. 123):

Although anthropology legitimated thefts of objects, and some disastrous physical and material consequences for Indigenous peoples, this complicity of anthropology with the violence of colonialism can also be considered in epistemic terms. 
Epistemic violence is a term (used) to refer to the process of writing so-called empirical history in the West. That which is represented as fact is, rather, a process of epistemic violence against those whose histories are denied. For example, the imposition of the processes of objectivist science through the institutions of the colonial state can be argued as doing epistemic violence to alternative ways of knowing the world.

\subsection{Illusions of Equality, Denial of Interrogation and Conflict}

McConaghy (2000) further argues that the anthropological notion of culture and the binary logic of objectivist science and philosophy also created the idea of cultural incommensurability, the idea that there exist two distinct cultural and racialised groups indigenous and non-indigenous - that are "oppositional in almost every sense" (McConaghy, 2000, p. 100). This notion gives too much emphasis to difference instead of connectedness, and closes all possibilities for meaningful interaction. Because of incommensurability, there are no higher or lower cultures, no superior or inferior knowledge. An implicit claim of equality is made, a claim that is deceptive. It denies the fact that Western societies have for long enjoyed the upper hand in the encounter - the dominance of Western cultures over other cultures is a hallmark of modern civilization.

The notion of cultural incommensurability may be linked to the idea of cultural relativism, which holds that one can only understand a specific society's practices within its specific cultural context (Moore, 1997). For holding that truth or value is relative to milieu or that intelligibility is entirely contextual, relativism, just like incommensurability, eschews the very possibility of interrogation and confrontation (Mendoza, 2001).

For Canclini (1993), whilst cultural relativism "helps to transcend ethnocentrism, it leaves certain fundamental problems of a theory of culture unanswered, namely, the creation of a universally valid body of thought and of criteria that can help conceptualize and solve conflicts and inequalities between cultures" (Canclini, 1993, p. 7). Even though cultural relativism has considerable value in its celebration of difference and in countering the oppressive aspects of assimilationism (McConaghy, 2000), Canclini (1993, p. 8) believes that:

Ultimately, cultural relativism founders because it rests on an atomized and naïve conception of power: it pictures each culture existing with no knowledge of others, as if the world were a vast museum of self-sufficient economies, each one in its own display 
case, unruffled by the proximity of others, invariably reenacting its own codes, its own internal relations. The limited usefulness of cultural relativism is demonstrated when we consider that it gave rise to a new attitude toward remote cultures, but it carries no weight when the "primitives" constitute the "backward" sectors of our own society, those customs and beliefs in the suburbs of our own cities that are alien to us.

The claims of cultural relativism cannot be isolated from the logic of capitalism. Driven by capitalist expansion, various forms of cultural production, including knowledge, are assimilated into a unified system and to some extent homogenised. Canclini (1993, p. 8) explains that this homogenisation does not mean equality in the distribution of resources, only an illusion of equality is created.

The dangers of homogenisation forewarned by Canclini (1993) in spite of the persistence of differences and hybridisation seem paradoxical. However, this could be explained by the concept of cultural postmodernity developed by Peters (2001, p. 9):

Cultural postmodernity, is a concept that, simultaneously and paradoxically, refers both to processes of differentiation - cultural difference - and homogenisation. The former refers to increasingly complex differentiation of culture both internal to the West and also the grudging recognition of non-Western traditional and indigenous cultures, which have followed decolonisation mostly as a result of ethnic struggles against the metropolitan state. The later set refers to the economic processes of commodification and the different consumer forms culture takes within an emerging global culture - most conspicuously, food, fashion, and tourism; most pervasively, news, TV, movies and the new electronic media, and; most powerfully, perhaps, intellectual products, ideas and theories (emphasis mine).

The spread of Western mathematics is one of the intellectual products that played a role in the creation of a 'global culture' and the move towards homogenisation and a unified system of knowledge.

\section{EVOLVING VIEWS, EMERGING CONCEPTION}

With the turn to social/cultural in intellectual thought, the anthropological notion of culture is increasingly being challenged. Now, culture is viewed as "essentially mutable and labile" (Carrithers, 1992, p.7). Expounding on the idea of a living culture, Carrithers (1992, p. 9) says:

Change, creation and re-creation, interpretation and re-interpretation, are all part of the fabric of everyday experience. These are not processes, which occur occasionally and exceptionally, but are rather the very stuff of human social life. Even when we do something that seems traditional, we do so in new conditions, and so are in fact recreating tradition rather than simply copying it. 
Alangui, W. V. (2019). Beyond songs and dances: Ethnomathematics and the challenge of culture. Revista Latinoamericana de Etnomatemática, 13(3), 88-107. DOI: 10.22267/relatem.20133.63

The above discussion suggests that a more appropriate conception of culture is needed to capture the realities of a globalising world, in an era of cultural postmodernity. As Peters (2001, p. 12) argues, "globalisation ... tends to bring into question more and more the concept of a single enclosed culture bounded by the nation-state or enclosed by the closed system of ethnic solidarity." What is needed is a notion that "recognises the fluidity, interaction and hybridisation of cultures today" (Peters, 2001, p. 13) as well as a notion that effects substantive changes in structures and relations of power and knowledge (McConaghy, 2000).

The notion of culture that I propose for the field of ethnomathematics responds to the challenges above (Alangui, 2010). Furthermore, it is a notion of culture that is consistent with the idea of internationalism whilst taking cognisance of the reality of globalisation and its attendant difficulties. This notion is drawn from the ideas of Wolfgang Welsch and James Tully, who each use a conception of culture they both attribute to Ludwig Wittgenstein.

Welsch (1999) perspective of transculturalism builds on Wittgenstein's notion of culture as shared practices (Peters, 2001). Welsch (1999) argues that Wittgenstein's concept of culture is "free of ethnic consolidation and unreasonable demands for homogeneity." He writes (Welsch, 1999, pp. 202-203):

According to Wittgenstein, culture is at hand whenever practices in life are shared. The basic task is not to be conceived as an understanding of foreign cultures, but as an interaction with foreignness. Understanding may be helpful, but is never sufficient alone, it has to enhance progress in interaction. We must change the pattern from hermeneutic conceptualisations with their beloved presumption of foreignness on the one hand and the unfortunate appropriating dialectics of understanding on the other to decidedly pragmatic efforts to interact. And there is always a good chance for such interactions, because there exist at least some entanglements, intersections and transitions between the different ways of life. It is precisely this which Wittgenstein's concept of culture takes into account. Culture in Wittgenstein's sense is, by its very structure, open to new connections and to further feats of integration. To this extent, a cultural concept reformulated along Wittgenstein's lines seems to me to be particularly apt to today's conditions.

Tully (1995), in his work on modern constitutionalism, argues for an aspectival notion of culture, a view he also traces to Wittgenstein (Peters, 2001). This notion of culture is based on a belief of cultures as overlapping, interactive and internally differentiated as opposed to cultures that are separate, bounded and internally uniform. He proposes a view of cultures that overlap geographically, and where cultures are "mutually defined through complex 
historical patterns of historical interaction, and they are continuously transformed in interaction with other cultures" (Tully, 1995, p.13).

In more ways than one, it is true that "culture emerges to help us make sense out of a world that could no longer be accounted for by existing ways of thought” (Ray, 2001, p. 185).

The fact that 'culture' has become a highly differentiated concept and increasingly important in social and policy studies (Peters, 2001) makes it all the more important to clarify what it means for practitioners in the field of ethnomathematics, especially because some of the criticisms levelled at ethnomathematics revolve around the very concept of culture (Eglash, 2000; Vithal \& Skovsmose, 1997).

The debate around the culture concept is indeed complex, yet it can only lead us to a situation where we can better articulate the perspectives of ethnomathematics, and the reasons why it is important to value other forms of mathematical knowledge. I argue that an important role for ethnomathematics is to help us understand these forms of mathematical/cultural knowledge, how these interact and might influence each other.

\section{ETHNOMATHEMATICS AND THE CHALLENGE OF CULTURE}

There are several challenges that ethnomathematics needs to address regarding the concept of culture because of the assumption that culture and mathematics are intimately and dialectically connected.

The first is a challenge directed at ethnomathematical studies that deal with indigenous peoples. It is the challenge of essentialism, of what Eglash (1997) calls primitivist romanticism - the idea that culture is harmless, innocent, authentic, exotic, and all good. This tendency is reinforced by the anthropological notion of culture. Ethnomathematical studies looking at the mathematical ideas of non-Western cultures need to be careful not to portray a romantic/romanticised view of indigenous (mathematical) knowledge. As suggested by Eglash, such a view is reductionist as it implies that non-Western knowledge is ahistorical and unchanging.

The second challenge concerns the implications of the ethnomathematical programme. It is the challenge of how to deal with cultural incommensurability and relativism. McConaghy's 
work on indigenous education in Australia shows that the notion of each group of people having its own integrity and its own values has been used as "an intellectual justification for segregated schools, housing, sexual sanctions and apartheid" (McConaghy, 2000, p.191). She argues that whilst cultural relativism has been used to justify programmes that support inclusion, it has also been used to exclude. In ethnomathematics, this difficulty has been reflected in debates about the relevance and dangers of an ethnomathematical curriculum, of writing "under the multicultural mathematics rubric which are far less attentive to educational requirements, sacrificing mathematical content for a third-world cultural gloss" (Eglash, 2000 , p. 20). Fossa $(1998$, p. 9) fears that "ethnomathematics, in the name of respecting cultural diversity, would ironically become a tool for the perpetual subjugation of the poor and the downtrodden."

Welsch's use of culture as shared practices, and Tully's elaboration of culture as aspectival are particular readings of Wittgenstein's notion of culture that allows ethnomathematicians to critically reflect on ethnomathematics and its relationship to mathematics. This notion of culture (Alangui, 2010; forthcoming):

- Recognises human agency;

- Implies fluidity and hybridisation;

- Connotes differentiation and rejects homogeneity;

- Argues for the necessity of interrogating foreignness;

- Recognises geographical overlaps, entanglements and intersections leading to a new conception of cultural difference; and

- Accounts for continuous change and transformation through interaction.

This conception, with its emphasis on interaction and interrogation, acknowledges the power of collective as well as individual agency in creating history and knowledge. People are actively engaged in transformation. The capacity to return the gaze, to actively interact and interrogate back means there is a capacity to pursue the collective's internal as well as individual perspective whilst being open to the possibilities of change that may be brought about by these processes. In such a situation, human subjectivity is always present and active. Awareness of the debate on culture, and acknowledging assumptions about culture can help ethnomathematicians direct the field away from being a tool for the perpetual subjugation of the poor and the downtrodden (Fossa, 1998), or one that is guilty of tokenism, where the 
value of non-Western traditional and indigenous cultures is grudgingly recognised (Peters, 2001).

\section{CRITICAL ISSUES: DOWLING'S MYTHS}

Ethnomathematics has not yet successfully attracted academic mathematicians under its umbrella. Many are sceptical about ethnomathematics (Rowlands \& Carson, 2002; Vithal \& Skovsmose, 1997). Here, I focus on Dowling's myths (1998) to develop what I call the dual dangers of ideological colonialism and knowledge decontextualisation that we might encounter in the field.

In The Sociology of Mathematics Education: Mathematical Myths/Pedagogical Texts, Dowling (1998) presented three myths that he describes as "concerned with the relationship between mathematics and other cultural practices" (Dowling, 1998, p. 4). Two of these myths, the myth of reference and the myth of emancipation, are deemed by this author as critical to, and of, ethnomathematical practice.

In the myth of reference, Dowling criticises the tendency to create division between the intellectual (as represented by mathematics) and the manual (domestic/cultural practice), and where the intellectual generates commentary on the manual. In this division between the intellectual and the manual, one moves between two spheres of activity, from one setting to another where one sphere of activity or setting always has to be mathematics. He says (Dowling, 1998, p. 6):

It is as if the mathematician casts a knowing gaze upon the non-mathematical world and describes it in mathematical terms. I want to claim that the myth is that the resulting descriptions and commentaries are about that which they appear to describe, that mathematics can refer to something other than itself.

Whilst Dowling does not specifically refer to ethnomathematics in his myth of reference, his criticism about the use of mathematics to describe and judge domestic or cultural practice, in his words, to recontextualise activity, is worth considering. The relevant question to ask is whether ethnomathematics, in attempting to describe and 'uncover' mathematical ideas 'present' in domestic/cultural practice, generates its own myth of reference. Might ethnomathematics, like mathematics, refer to something other than itself? What does it mean, for example, to talk about and describe the ethnomathematics of a particular culture? The 
answer depends on how ethnomathematics is defined, understood and practised. Studies that describe the 'mathematics' of cultural practice are prevalent in the field, which is a reflection of a particular reading of the concept of ethnomathematics. This particular reading of ethnomathematics has an inherent danger - the recontextualisation of cultural practice in purely mathematical terms might diminish cultural meaning and value, resulting to knowledge decontextualisation.

One example comes to mind, and it is a project that I was involved in along with the faculty of the Discipline of Mathematics of the University of the Philippines College Baguio (1996). We set out to study the mathematics behind the weaving patterns, gong music and kinship systems of the northern Kankana-ey of Mt. Province. Whilst there was a careful attempt to describe the cultural context of these Kankana-ey practices, the motivation was primarily to determine whether they exhibited 'nice' algebraic structures. Guided by the desire to explain these practices mathematically, our output concluded the presence of deep mathematical knowledge in Kankana-ey weaving, gong music and kinship systems, entirely relegating to the background their significance in the social and cultural life of the people.

Recently, there has been a growing interest among mathematics educators in the Philippines on ethnomathematics, encouraged primarily by recent government policies supporting indigenous peoples education both at the primary and university levels. Unfortunately, many of the studies I have seen thus far, or those being planned, tended to reflect the myth of reference.

For example, proponents of one tutorial program sent me a list of questions for their plan to "teach" a particular group of indigenous students in the country about "their ethnomathematics." The following question took me aback:

What if the teachers have no access to the community's traditional songs and dances? What other cultural aspects can be used (or have been used by other teachers)?

Now, with the benefit of hindsight, my reply to this question showed some degree of exasperation:

Culture is not only about songs and dances; please re-visit/re-think/re-view/critically interrogate your concept of culture; the danger of using a limited concept of culture is that we might be reinforcing stereotypes and superficial ideas; read on the 
anthropological concept of culture and understand how this view perpetuates a backward concept of culture; once you re-view culture as going beyond songs and dances, you will realize that there is a whole complex knowledge system of indigenous peoples that could be a rich source of material to make the curriculum relevant, responsive and culturally sustaining for the communities/people/students.

Another proposed project which I was asked to comment on wanted to study the 'ethnomathematics' of another indigenous group in the country, while a published study analysed the symmetries of weaving of some indigenous textiles, which was not much different from what our discipline did on the weaving patterns of the northern Kankana-ey people.

At one level, these studies could be following the "folkloristic view" that D'Ambrosio (1999a, p. 51) predicted early on in his search for the term ethnomathematics, a view that fails to locate the practice, and its significance, in the overall fabric of social and cultural life. What happens is that certain elements of the culture (for example, weaving, songs and dances) are isolated and become the focus of an ethnomathematical study simply by virtue of its perceived 'mathematical significance.'

At another level, recontextualising cultural practice also faces the epistemological dilemma of how to regard elements of the practice as mathematical (Begg, 2001) without imposing one's categories and constructs. This is the essence of Millroy's (1992) paradox. The implication is that once a practice becomes the subject of an ethnomathematical study, there is necessarily a shifting of cultural context.

Both situations can lead to the same problem. Recontextualisation might result in decontextualisation, which ironically, is not what ethnomathematics is about.

The other myth presented by Dowling is that of emancipation, which he directly links to ethnomathematics. Dowling associates ethnomathematics with "a growing body of work (that) seeks to celebrate an alreadiness of mathematical content within the practices of different cultural groups" (Dowling, 1998, p. 12).

Unlike the myth of reference, Dowling argues that the myth of emancipation assumes a unification of the mathematical and the non-mathematical. The similarity is that both myths 
project a mathematical gaze onto the non-mathematical. The myth propagated by ethnomathematics (Dowling, 1998, p 15):

... entails a celebration of the supposed mathematical practices of non-European societies. Revealing the truly mathematical content of what might otherwise be regarded as primitive practices elevates the practices, and ultimately emancipates the practitioners... European mathematics constitutes recognition principles which are projected onto the other, so that mathematics can be 'discovered' under its gaze. The myth announces that the mathematics was there already.

Whilst the myth of reference does not deny, nor attempt to hide the intellectual/manual (or mathematical/non-mathematical) divide, the myth of emancipation denies that such a division in the cultural domain exists. For Dowling, this is exactly the problem, and which he regards as ultimately deceptive. He says (Dowling, 1998, p. 17) "the denial is itself mythical, because the myths are concealing the self-referential origin of the gaze which constructs (its) texts."

Dowling takes to task the works of Paulus Gerdes, Claudia Zaslavsky and Alan Bishop. Zaslavsky is best known for her book Africa Counts, which documents the history of mathematical ideas in Africa and what she believes as the continent's unacknowledged contributions to the growth of Western mathematics. The book pre-dates ethnomathematics and is a pioneering work on the interplay of mathematics, culture and history (Zaslavsky, 1973). Alan Bishop does not regard himself as an ethnomathematician, although he has devoted substantial work in the conceptualization of mathematics as a socio-cultural phenomenon. Ethnomathematical researchers often refer to his list of six fundamental activities, which he regards as universal amongst all cultures. These fundamental, premathematical activities are counting, locating, measuring, designing, playing, and explaining (Bishop, 1988).

Whilst Dowling regards Bishop's fundamental activities as "gross reductions" (Dowling, 1998, p. 14) of cultures and Zaslavsky's work as patronizing and objectifying "the African" (Dowling, 1998, p. 15), he reserves his most serious criticisms for Gerdes.

Gerdes clearly identifies his work as ethnomathematics, linking his process of defrosting hidden mathematical ideas in traditional production techniques to a project of cultural rebirth, to what he calls a cultural-mathematical reaffirmation that combats racial and colonial 
prejudice (Gerdes, 1986, 1991, 1997). Whilst Gerdes regards his work as contributing to the process of decolonisation, Dowling argues that Gerdes achieves quite the opposite. For Dowling, the most problematic aspect of Gerdes work in Africa relates to the concealed selfreferential origin of the gaze, which is fundamentally 'European'. In Gerdes' work, Dowling (1998, p. 12) claims that the African culture is not allowed to speak for itself. The implication is that Gerdes unwittingly perpetuates the supremacy of white culture by silencing the voice(s) of other cultures.

The same problem of decontextualisation observed earlier with the myth of reference is also operative in the myth of emancipation. Because cultural/non-mathematical practices are described using European mathematical categories, they are once again "deprived of their social and cultural specificity" (Dowling, 1998, p. 14).

Commenting on Gerdes' view of mathematics as a particular set of activities (which is relative to a particular world view), Barton (1996, p. 63) makes a similar observation and reiterates the peril of colonisation of knowledge:

Gerdes' use of the idea of mathematics as an activity gets around some of the problems of a relativist philosophy, but other problems remain. For example, the concept of mathematics as a category of activity in any culture is a Western idea. Other cultures do not recognize 'mathematics' as separate from some other aspects of their culture - it cannot be isolated out. How, then, does the union of all ethnomathematics come about? Does it include all the other parts of other cultures which are regarded as inextricably linked? If not, then the Western idea of mathematics is being adopted, which is another expression of ideological colonialism.

One example of how colonisation of knowledge might happen in ethnomathematics is found in Barton (2008), where he describes his involvement in the development of a mathematical vocabulary in the Maori language as a response to the call for mathematics (and science) instruction in Maori. Whilst this particular project was not made under the rubric of ethnomathematics, it exemplifies the interplay of mathematics and cultural elements, showing how one form of knowledge (the Maori language) may be used to make the other (mathematical knowledge) more accessible. This was in 1987. The development of a Maori mathematical vocabulary went through a painstaking process that involved teachers, mathematicians, mathematics educators, linguists, Maori elders, and Maori language experts and was made "under strict guidelines laid down by the Maori Language Commission 
(Barton, 2008, p. 2). Despite this, he describes increasing discomfort about some aspects of their work (Barton, 2008, pp. 3-4):

Somehow, the mathematical discourse that had developed did not feel right, but we were unable to put our finger on why. We came to talk about this as the "Trojan Horse" phenomenon: mathematics education seemed to be a vehicle that led to the subtle corruption of the ethos of the Maori language.

For Barton, the work became an example of how one language (English) might come to colonise another (Maori). He explains that with the project, "a grammatical corruption had happened" (Barton, 2008, p. 4) where the verbal nature of numbers (as it was in Maori before European contact) was ignored, and a classroom discourse that treated numbers as they are in English (adjectival) was perpetuated (Barton, 2008). He laments that the project "fundamentally permanently changed the nature of the language" (Barton, 2008, p 4).

The examples mentioned in this study where decontextualisation and colonisation occurred (the study on the algebra of weaving, gong music and kinship systems of the Kankana-ey including the other studies in the Philippines, and the Maori mathematical vocabulary project) give weight to the criticisms about the concealed referential gaze that is mathematics and the problems engendered by this gaze.

\section{CONCLUSION}

Following Barton's definition of ethnomathematics (Barton, 1996), the use of mathematics as a lens to study a non-mathematical practice may be difficult to avoid. These criticisms need to be acknowledged and addressed especially if the focus of an ethnomathematical study is a practice of a particular indigenous or cultural group.

The concept of culture that I suggested above and the use of mutual interrogation (Alangui, 2010) as a methodological approach may help resolve these issues. Recontextualisation may be seen as a shift in cultural context, an instance of culture change that is driven by necessity. Such a necessary change is consistent with the way this study views culture as mutable and labile.

Complementary to this concept of culture is a process of mutual interrogation between mathematical knowledge and knowledge embedded in cultural practice. To reiterate briefly, 
mutual interrogation (Alangui, 2010) is an approach in ethnomathematics in which the ethnomathematician:

- Sets up a critical dialogue between cultural practice and mathematics;

- Draws up parallels between the two practices, using elements in one system to ask questions of the other;

- Engages in a series of reflection and questioning of assumptions about mathematics; and

- Explores alternative conceptions.

Through critical dialogue and reflection, the context and meaning of cultural knowledge is not lost in the process, and tendencies to colonise knowledge are dashed. Reconceptualising culture, and adopting mutual interrogation as a methodological stance, will help position ethnomathematics as a discipline that assists in the realization of vision D'Ambrosio (1999b, 2000) of a new planetary order without inequity, arrogance and bigotry.

\section{REFERENCES}

Alangui, W. (2010). Stone Walls and Water Flows: Interrogating Cultural Practice and Mathematics. Auckland, New Zealand: University of Auckland.

Alangui, W., \& Barton, B. (forthcoming). The concept of culture and its challenge to ethnomathematics. Paper presented at the Sixth International Congress on Ethnomathematics (ICEM6), Medellin, Colombia.

Alangui, W., \& Barton, B. (2002). A Methodology for Ethnomathematics. Paper presented at the Second International Congress on Ethnomathematics (ICEM2), CD Rom, Ouro Preto, Brazil.

Appadurai, A. (1990). Disjuncture and difference in the global cultural economy. Public Culture, 2(2), 1-24.

Barton, W. D. (1996). Ethnomathematics: Exploring Cultural Diversity in Mathematics. The University of Auckland, Auckland.

Barton, B. (2008). The Language of Mathematics: Telling Mathematical Tales. New York: Springer.

Begg, A. (2001). Ethnomathematics: Why, and What Else? Zentralblatt fur Didaktik der Mathematik, 33(3).

Bishop, A. (1988). Mathematics Enculturation: A Cultural Perspective on Mathematics Education. Dordrecht: Kluwer Academic Publishers.

Boas, F. (1938). The Mind of Primitive Man (Rev. ed.). New York: The Free Press. (Original work published 1911) 
Bourdieu, P. (1977). Outline of a Theory of Practice (R.Nice, Trans.). Cambridge, England: Cambridge University Press. (Original work published 1972)

Canclini, N. G. (1993). Transforming Modernity: Popular Culture in Mexico (L. Lozano, Trans.). Austin: University of Texas Press.

Carrithers, M. (1992). Why Humans have Cultures: Explaining Anthropology and Social Diversity. Oxford: Oxford University Press.

Clifford, J. (1988). The Predicament of Culture: Twentieth-Century Ethnography, Literature, and Art. Cambridge: Harvard University Press

D'Ambrosio, U. (1999a). Ethnomathematics and Its First International Congress. Zentralblatt fur Didaktik der Mathematik, 31(2), 50-53.

D'Ambrosio, U. (1999b). Literacy, Matheracy, and Technocracy: A Trivium for Today. Mathematical Thinking and Learning, 1(2), 131-153.

D'Ambrosio, U. (2000). A Historiographical Proposal for Non-Western Mathematics. In H. Selin (Ed.), Mathematics Across Cultures: The History of Non-Western Mathematics (Vol. 2, pp. 79-92). The Netherlands: Kluwer Academic Publishers.

D'Andrade, R. (1995). Moral Models in Anthropology. Current Anthropology 36(3), 399418.

Dowling, P. (1998). The Sociology of Mathematics Education: Mathematical Myths/Pedagogical Texts. London and Washington D.C.: The Falmer Press.

Eglash, R. (1997). When Math Worlds Collide: Intention and Invention in Ethnomathematics. Science, Technology \& Human Values, 22(1), 79-98.

Eglash, R. (2000). Anthropological Perspectives on Ethnomathematics. In H. Selin (Ed.), Mathematics Across Cultures: The History of Non-Western Mathematics (Vol. 2, pp. 13-22). Dordrecht: Kluwer Academic Publishers.

Fantinato, M.C. \& Sousa Mafra, J. R. (2016). Techniques and Learning Processes of Craftswomen in Brazil. In M. Rosa, L. Shirley, ME Gavarette \& W. Alangui (Eds.). Ethnomathematics and its Diverse Approaches for Mathematics Education (pp. 6995). Cham: Springer International Publishing AG

Fossa, J. (1998). How to give ethnomathematics a bad name. ISGEM Newsletter, 14(12).

Foucault, M. (1972). The Archaeology of Knowledge. New York: Pantheon Books.

Fritze, R. (2002). New Worlds: The Great Voyages of Discovery 1400-1600. Westport, CT and London: Praeger Publishers.

Gerdes, P. (1986). How to Recognise Hidden Geometrical Thinking? A Contribution to the Development of Anthropological Mathematics. For the Learning of Mathematics, 6(2), 10-12.

Gerdes, P. (1991). Lusona: Geometrical Recreations of Africa. Maputo: Eduardo Mondlane University Press. 
Gerdes, P. (1997). On Culture, Geometrical Thinking and Mathematics Education. In A. Powell \& M. Frankenstein (Eds.), Ethnomathematics: Challenging Eurocentrism in Mathematics Education (pp. 223-247). Albany: State University of New York Press.

Gramsci, A. (1971). Selections from the Prison Notebooks of Antonio Gramsci. New York: International Publishers.

Hottinger, S. (2016). Inventing The Mathematician: Gender, Race and Our Cultural Understanding of Mathematics. Albany: SUNY Press.

Knijnik, G. (2002). Ethnomathematics: Culture and politics of knowledge in mathematics education. For the Learning of Mathematics, 22(1), 11-14.

Malinowski, B. (1961). Argonauts of the Western Pacific. New York: Dutton. (Original work published 1922)

McConaghy, C. (2000). Rethinking Indigenous Education: Culturalism, Colonialism and the Politics of Knowing. Queensland: Post Pressed.

Mendoza, J. (2001). The Condition of Indigenous Knowledge (IK) from a Structurationist Perspective. In V. Rico-Costina \& M.-L. Difuntorum (Eds.), Towards Understanding Peoples of the Cordillera: A Review of Research on History, Governance, Resources, Institutions and Living Traditions (Vol. 2. 47-67). Baguio: Cordillera Studies Center, University of the Philippines Baguio.

Millroy, W. L. (1992). An Ethnographic Study of the Mathematical Ideas of a Group of Carpenters. Journal for Research in Mathematics Education, 5 (1-210).

Moore, J. (1997). Visions of Culture: An Introduction to Anthropological Theories and Theorists. Walnut Creek: AltaMitra Press.

Parra, A. (2017). Ethnomathematical Barters. In H. Straehler-Pohl, N. Bohlmann, A. Pais (Eds). The Disorder of Mathematics Education (pp. 89-105). Cham: Springer International Publishing.

Peters, M. (2001). Cultural Postmodernity in Aotearoa/New Zealand: Biculturalism, Multiculturalism and Transculturalism. Auckland: Unpublished manuscript.

Ray, W. (2001). The Logic of Culture: Authority and Identity in the Modern Era. Oxford: Blackwell Publishers Ltd.

Roberts, J.M. (1961). The Zuni. In F.R.Kluckhohn \& F.L.Strodtbeck (Eds.), Variations in value orientations (pp. 285-316). Evanston: Row, Peterson.

Rowlands, S., \& Carson, R. (2002). Where Would Formal, Academic Mathematics Stand in a Curriculum Informed by Ethnomathematics? A Critical Review of Ethnomathematics. Educational Studies in Mathematics, 50(1), 79-102.

Said, E. (1978). Orientalism. New York: Vintage Books.

Smith, L. T. (1999). Decolonizing Methodologies: Research and Indigenous Peoples. London \& New York: Zed Books Ltd. 
Stathopoulou, C. (2016). Once Upon a Time... The Gypsy Boy Turned 15 While Still in the First Grade. In M. Rosa, L. Shirley, ME Gavarette \& W. Alangui (Eds.). Ethnomathematics and its Diverse Approaches for Mathematics Education (pp. 97 124). Cham: Springer International Publishing AG.

Strauss, C. (2000). The Culture Concept and the Individualism-Collectivism Debate and Alternative Attributions for Class in the United States. In L. Nucci, G. Saxe \& E. Turiel (Eds.), Culture, Thought and Development. New Jersey: Lawrence Earlbaum Associates, Inc.

The Faculty of the Discipline of Mathematics, UP College Baguio. (1996). The Algebra of the Weaving Patterns, Gong Music, and Kinship System of the Kankanaey of Mountain Province. Quezon City: Center for Integrative and Development Studies, University of the Philippines and the Department of Education, Culture and Sports Republic of the Philippines.

Tully, J. (1995). Strange Multiplicity: Constitutionalism in an Age of Diversity. Cambridge: Cambridge University Press.

Vincent, J. (1991). Engaging Historicism. In R. G. Fox (Ed.), Recapturing Anthropology. Santa Fe: School of American Press.

Vithal, R., \& Skovsmose, O. (1997). The End of Innocence: A Critique of 'Ethnomathematics'. Educational Studies in Mathematics, 34. pp. 131-157.

Wallace, A.F.C. (1970). Introduction. In Culture and personality, $2^{\text {nd }} E d$. (pp. 3-38). New York: Random House.

Welsch, W. (1999). Transculturality: The Puzzling Form of Cultures Today. In M. Featherstone \& S. Lash (Eds.), Spaces of Culture: City, Nation, World (59-86). London: Sage Publications Ltd.

Wolf, E. (1982). Europe and the People without History. London: University of California Press.

Zaslavksy, C. (1973). Africa Counts. Boston, MA: Prindle, Weber \& Schmidt, Inc. 